\title{
Prevalence of Chlamydia trachomatis in Human Immunodeficiency Virus-infected Women in Cuba
}

\author{
Vivian Kouri/ ${ }^{+}$, Judith Cartaya, María E Rodríguez*, Mayra Muné, Yudira Soto, Sonia Resik, \\ Jose Bravo**, Alina Llop***
}

Departamento de Virología *Departmento de Dermatología **Departmento de Bioestadística ***Sub-directora de Microbiología, Instituto de Medicina Tropical "Pedro Kouri", Autopista Novia del Mediodía, km 6, La Lisa, Ciudad de la Habana, Cuba

To determine the prevalence rates and serovar distribution of Chlamydia trachomatis cervical infections in Cuban women, two different groups were selected. Group I consisted of 60 human immunodeficiency virus (HIV-1) seropositive women from different regions of Cuba and group II of 60 randomly selected women HIV seronegative and apparently healthy. $\mathrm{C}$. trachomatis was detected in cervical scrapes by mean of nested polymerase chain reaction $(P C R)$ specific for major out membrane protein. The overall prevalence rate of $\mathrm{C}$. trachomatis in cervical scrapes determined by nested PCR was $10 \%$ in group I and the estimated prevalence was $6.6 \%$ for group II; $83.3 \%$ of HIV seropositive women with $\mathrm{C}$. trachomatis infection reported history of pelvic inflammatory disease followed by cervicitis (50\%). The control group C. trachomatis-infected women referred a history of cervicitis in $75 \%$ of cases. Other reports in the latter group included infertility and pelvic inflamatory disease in 50\%. The present study is the first report of $\mathrm{C}$. trachomatis prevalence in Cuba. It showed that there was not significantly difference in the prevalence rate of $\mathrm{C}$. trachomatis between both groups.

Key words: Chlamydia trachomatis - prevalence - human immunodeficiency virus (HIV) - Cuba

Chlamydia trachomatis is a ubiquitous microorganism and one of the most common agent of sexually transmitted infections (STI). The number of these infections is displaying an increasing tendency worldwide (Déak et al. 1997). The prevalence of $C$. trachomatis genital infections in women has been reported ranging from 0 to $37 \%$, depending on the population studied and the techniques used (Lan et al. 1995, Assefa et al. 1998).

Several risk factors play a role in this tendency: age under 25, family status, education, beginning of sexual activity and number of sexual partner among others (Oakeshott \& Hay 1995).

Genital infections produced by $C$. trachomatis mainly affect women, who develop cervical infections and urethritis, and a substantial number has an asymptomatic course (Adler 1996, Ramjee et al. 1998, Colvin et al. 1998). In adults, complications include infertility, pelvic inflamatory disease (PID), ectopic pregnancy, premature rupture of membranes, pre-term-birth, puerperal infections and facilitation of human immunodeficiency virus (HIV) type 1 transmission (Temmerman 1994, Chaisilwattana et al. 1997).

Currently, 16 serovars of $C$. trachomatis have been identified; 60 to $70 \%$ of urogenital syndromes are produced by serovars E, F and D (Naher \& Petzoldt 1991, Paavonen 1996).

The polymerase chaim reaction (PCR) technology developed in recent years allows the detection of small quan-

$\overline{{ }^{+} \text {Corresponding author. Fax }}$ +53-7-2046051. E-mail: vkouri@ipk.sld.cu

Received 8 November 2001

Accepted 23 September 2002 tities of specific nuclei acids and have been proposed by different authors as an alternative methodology for $\mathrm{C}$. trachomatis diagnosis (Lan et al. 1995, Le Bar 1996).

In the present study, the prevalence rate of $C$. trachomatis infections was investigated in Cuban HIVinfected women and the estimated of prevalence in healthy seronegative women. Nested PCR was employed to amplify a large part of the major out membrane protein (MOMP) gene, and then cataloged restriction fragment length polymorphism (RFLP) to distinguish serovars of C. trachomatis.

\section{MATERIALS AND METHODS}

Study population - The present study was performed from November 1996 to March 1997 at the Institute of Tropical Medicine "Pedro Kouri" (IPK). At the moment of the study there were $350 \mathrm{HIV}-1$ infected women in Cuba. Two different populations were investigated for the prevalence of $C$. trachomatis cervical infections. Group I consisted of 60 HIV-1 seropositive women randomly selected from the National Registry of HIV patients in Cuba, and the selected patients agree to participate in the study. All patients from distant regions of the country were transported to the IPK for testing. The random selection was made by means of a table of random number using a simple random sample method. Group II consisted of 60 HIV seronegative women apparently healthy who were invited to participate in this study as control group; they were selected from IPK workers as well as from mothers who bring their children to the outpatient service of the Institute. This group was mainly composed of individuals from Havana City, although 12 (20\%) came from other cities.

Both groups ranged between 15 to 50 years of age. They were requested to complete an anonymous questionnaire regarding previous gynecological history (infertility, PID, cervicitis, among others) as well as some 
epidemiological data (age, number of sexual partners) and afterward they were carefully physically examined. An HIV test was performed to each seronegative woman at the first visit, and CD4 count was determined to all HIV seropositive women.

The study has institutional ethics approval and all patients read the informed consent.

Sample collection and processing - Cervical scrapes were collected with cervix brushes, placed in $1 \mathrm{ml}$ of media (phosphate-buffered saline, PBS 1X pH 7.2 and SDS $0.001 \%$, Dygene) and transported to the laboratory. The samples were centrifuged at $3200 \mathrm{x}$ g and the pellet was suspended in $500 \mu$ l of digestion buffer (Tris $10 \mathrm{mM}$, EDTA $10 \mathrm{mM}, \mathrm{SDS} 0.5 \%, \mathrm{NaCl} 10 \mathrm{mM}$ ) and $10 \mu \mathrm{l}$ of proteinase $\mathrm{K}$ $(20 \mathrm{mg} / \mathrm{ml})$ and incubated at $56^{\circ} \mathrm{C}$ for $1 \mathrm{~h}$. Finally, DNA was extracted with phenol-chloroform, ethanol precipitated and the pellet was resuspended in $10 \mu \mathrm{l}$ of distilled water, according to the protocol described by Innis et al. (1990), $5 \mu \mathrm{l}$ were used for the first reaction of nested PCR.

Nested PCR was first normalized using dilutions from pure to $10^{-10}$ of L2 strain (ATCC) previously tittered in tissue culture (Mc Coy Cells) which is the gold standard, in order to detect the number of inclusions forming units (IFU).

The primers used for the first reaction of nested PCR flanking a region of $1200 \mathrm{bp}$ from the MOMP gene while the second nested pair of primers were used to amplify a inner $305 \mathrm{bp}$ fragment from the same gene (Hayes et al. 1992). Negative and positive controls were also tested in each assay; they had been confirmed as positive or negative by tissue culture. We also employed distilled water as negative control, they were placed each five samples in order to check for cross-contamination between samples during the performance of the nested-PCR. Ten microliters of amplified products from the nested primer pair was analyzed on $2 \%$ agarose gel electrophoresis stained with ethidium bromide.

Once the amplified fragments were visible at the gel, nested PCR products were subjected to RFLP analysis using Alu I and Msp I (Promega) enzymes as described previously (Frost et al. 1993). The digestion products were separated on 10\% polyacrilamide gel in Tris-Borate buffer. Gel were ethidium bromide stained in order to see the bands.

All patients were also tested for other microorganisms that produce STI. For human papillomavirus (HPV) detection and mycoplasma (Ureaplasma urealiticum) PCR was employed (Manos et al. 1989, Teng et al. 1994), while for Neisseria gonorrhoeae, Trichomonas vaginalis, and Candida albicans, culture of the microorganisms was the technique assayed (Thayer \& Martin 1966, Fleming et al. 1977, Fouts \& Kraus 1980). For Treponema pallidum VDRL was the technique employed.

Statistic analysis - Data management was performed by the statistical program package Microstat and Chisquare statistical analysis with Yate correction; 95\% confidence interval was tested to ascertain whether the results were statistically significant. Odd Ratio was calculated for relative risk determination (Fleis 1981, Dawson \& Trapp 1993).

\section{RESULTS}

PCR normalization, DNA extraction and PCR assay - The sensitivity of PCR was determined using dilutions from pure to $10^{-10}$ of C. trachomatis L2 strain previously tittered in tissue culture in order to detect the number of IFU. By mean of tissue culture we detected 1 IFU in $10^{-5}$ dilution of $C$. trachomatis L2 strain. Our PCR system resulted more sensitive than tissue culture, since it was able to detect 0.1 IFU L2 DNA.

Of the 120 cases that were screened for C. trachomatis MOMP PCR, $10(8.3 \%)$ were found positive.

Prevalence - The overall prevalence rate of $C$. trachomatis in cervical scrapes determined by PCR was $10 \%$ (6 cases) in group I and the estimated prevalence was $6.6 \%$ ( 4 cases) for group II $(95 \% \mathrm{CI})$. The $C$. trachomatis positive scrapes detected by MOMP nested PCR were genotyped by RFLP analysis. Serovar E was found in six cases from both groups whereas serovar L2 was found in one HIV seropositive woman.

Epidemiological characteristics and risk factors Epidemiological data and risk factors for C. trachomatis between HIV seropositive and seronegative women are shown in the Table. HIV seropositive women with $C$. trachomatis tended to be younger than those without this infection, being statistically significant, although this finding was only present for group I.

In contrast, primigravida status and history of multiple sexual partners in the last five years was not significantly related to $C$. trachomatis infection.

The number of HIV seropositive women positive to $C$. trachomatis was associated with VDRL positive. Other factors, including CD4 count, hepatitis B surface antigen (HBsAg) and hepatitis $\mathrm{C}$ antibodies (HCV) were not significantly associated with this infection.

Aiming to make an analysis of the data collected in the questionnaire related to gynecological history referred by patients we concluded that the main complains among the group I with C. trachomatis infection was PID (5 out of 6 cases, $83.3 \%$ ), followed by cervicitis in 3 cases $(50 \%)$. In contrast, group II referred history of cervicitis in 3 cases $(75 \%)$. Other report in the latter group included infertility and PID in 2 cases $(50 \%)$.

At physical exam, cervicitis and vaginal discharge were present in $2(33.3 \%)$ and $1(16.6 \%)$ respectively in HIV infected women with $C$. trachomatis infection while for HIV seronegative women $C$. trachomatis-infected were present in $3(75 \%)$ and $1(25 \%)$ case respectively. Otherwise, there was a proportion of asymptomatic cases.

C. trachomatis and other pathogens co-infection The association of $C$. trachomatis in HIV seropositive and seronegative women with other pathogens also tested during this study is summarized as follow. In HIV seropositive women we found 22 positives to $T$. vaginalis, but only 1 was also positive to C. trachomatis (16.6\%), from 18 positives to $C$. albicans 2 resulted positives to $C$. trachomatis $(11.1 \%)$ and 5 out of 34 cases positives to HPV (14.7\%); only HIV seropositive women positives to C. trachomatis and VDRL (2 of 5 cases; 40\%) resulted statistically significant. For HIV seronegative group there was no significant relation between $C$. trachomatis and 
TABLE

Risk factors determinants for Chlamydia trachomatis infection and human immunodeficiency virus (HIV) infection status

\begin{tabular}{|c|c|c|c|c|c|c|c|c|}
\hline \multirow[t]{2}{*}{ Risk factor } & \multicolumn{3}{|c|}{ HIV positives } & \multirow[b]{2}{*}{$\chi^{2}$} & \multicolumn{3}{|c|}{ HIV negatives } & \multirow[b]{2}{*}{$\chi^{2}$} \\
\hline & $+\mathrm{Ct} /$ total & $\%$ & OR & & $+\mathrm{Ct} /$ total & $\%$ & OR & \\
\hline $\begin{aligned} \text { Age } & <20 \\
& >20\end{aligned}$ & $\begin{array}{c}3 / 5 \\
3 / 55\end{array}$ & $\begin{array}{l}60 \\
5.45\end{array}$ & $21^{a}$ & 15.15 & $\begin{array}{c}0 / 3 \\
4 / 57\end{array}$ & $\begin{array}{l}0 \\
7\end{array}$ & 3.39 & 0.253 \\
\hline $\begin{array}{l}\text { Primigravida } \\
\text { Multigravida }\end{array}$ & $\begin{array}{l}1 / 21 \\
5 / 39\end{array}$ & $\begin{array}{r}4.8 \\
12.8\end{array}$ & 2.18 & 0.985 & $\begin{array}{l}3 / 37 \\
1 / 23\end{array}$ & $\begin{array}{l}8.1 \\
4.3\end{array}$ & 1.52 & 0.322 \\
\hline $\begin{array}{l}1 \text { sex partner }+ \\
>1 \text { sex partner }\end{array}$ & $\begin{array}{l}2 / 23 \\
4 / 37\end{array}$ & $\begin{array}{r}8.6 \\
10.8\end{array}$ & 1.15 & 0.070 & $\begin{array}{l}2 / 25 \\
2 / 35\end{array}$ & $\begin{array}{l}8 \\
5.7\end{array}$ & 0.701 & 0.122 \\
\hline $\begin{array}{l}\text { HBs Ag-positive } \\
\text { HBs Ag-negative }\end{array}$ & $\begin{array}{c}0 / 4 \\
6 / 56\end{array}$ & $\begin{array}{l}0 \\
1.07\end{array}$ & 1.72 & 0.0068 & $\begin{array}{c}0 / 0 \\
4 / 60\end{array}$ & $\begin{array}{l}0 \\
6.66\end{array}$ & 12.556 & 2.703 \\
\hline $\begin{array}{l}\mathrm{HCV} \text { positive } \\
\mathrm{HCV} \text { negative }\end{array}$ & $\begin{array}{c}1 / 4 \\
5 / 56\end{array}$ & $\begin{array}{l}25 \\
8.9\end{array}$ & 4.013 & 1.071 & $\begin{array}{c}0 / 0 \\
4 / 60\end{array}$ & $\begin{array}{l}0 \\
6.66\end{array}$ & 12.556 & 2.703 \\
\hline $\begin{array}{l}\text { VDRL positive } \\
\text { VDRL positive }\end{array}$ & $\begin{array}{c}2 / 5 \\
4 / 55\end{array}$ & $\begin{array}{c}40 \\
7.3\end{array}$ & $8.175^{a}$ & 5.455 & $\begin{array}{c}0 / 0 \\
4 / 60\end{array}$ & $\begin{array}{l}0 \\
6.66\end{array}$ & 12.556 & 2.703 \\
\hline $\begin{array}{l}\text { CD } 4 \\
>500 \text { cell } / \mathrm{mm}^{3} \\
<500 \mathrm{cell} / \mathrm{mm}^{3}\end{array}$ & $\begin{array}{l}2 / 48 \\
4 / 14\end{array}$ & $\begin{array}{l}4.16 \\
28.5\end{array}$ & 4.37 & 1.160 & NA & & & \\
\hline
\end{tabular}

OR: odds ratio; +: no. of sexual partner in the last five years; $\chi^{2}$ : Chi-square; $\mathrm{Ct}$ : Chlamydia trachomatis; NA: not available; HbsAg: hepatitis B surface antigen; HCV: hepatitis C antibodies; VDRL: venereal disease research laboratory (titer); $a$ : statistically significant

any other pathogen, but we should remark that HPV and C. albicans infection were frequently detected ( 30 and 19 cases respectively).

\section{DISCUSSION}

PCR technology has been successfully employed during the last ten years for diagnosis of several microorganisms. Many studies related to $C$. trachomatis prevalence using PCR from cervical scrapers or urine have been done (Frost et al. 1991, 1993, Poulin et al. 2001, Garland et al. 2001), obtaining similar results. Other authors have compared for accuracy several methods like tissue culture or antigen detection with PCR and all of them have obtained excellent results with the latter, which has proven to have more sensitivity than tissue culture. It is also in agreement with the results that we obtained when our nested PCR was normalized (Cheng et al. 2001).

The present study demonstrated that the prevalence of $C$. trachomatis in HIV positive women in Cuba is higher but not significantly different from the estimated prevalence in the control group ( $>0.05)$. Those results are similar to other previous reports of prevalence in asymptomatics cervical infections, which range from 0 to 37\% (Déak et al. 1997, Assefa et al. 1998). Other authors in France and Spain reported prevalence rates of 7.1 and $6.3 \%$ respectively, being similar to the prevalence estimated for control group (Massé et al. 1991, García-Lechuz et al. 1999).

Few published reports regarding the prevalence of $C$. trachomatis in HIV positive women were found in the reviewed literature. In 1994, Spinillo et al. referred an 18.3\% of prevalence rate in HIV infected women, which resulted significantly higher to the prevalence obtained in the con- trol group that was $8 \%$. Anyway, they could not find any correlation between immunodepression and, similar to us, they did not find differences in the risk of development $C$. trachomatis infection cervical infection among HIV seronegative and seropositive women. Christenson and Stilstrom, in 1995, studied some STD in Sweden and they considered that, in contrast to other STI, $C$. trachomatis was the only agent affecting the population in the same way, including HIV women, this result is in agreement with our results. Minkoff et al. (1999) and García-Lechuz et al. (1999) reported similar results in recent studies.

In a similar way, Clark et al. (1993) and Calore et al. (1995) studied the behaviour of different STD in HIV infected patients, reporting prevalence rates of $12.3 \%$ and $3.4 \%$ respectively. Similar to previous studies (Douvier et al. 1996, Passey et al. 1998), we found significant relation between age under 25 and $C$. trachomatis infection, but it was only present for group I. CD4 count was low (less than 500 cells $/ \mathrm{ml}$ ) in 48 out of the $60 \mathrm{HIV}$ infected patients, but it was not related to $C$. trachomatis infection, based in our results we do not consider $C$. trachomatis infection to be directly related to the immune status.

We found PID and cervicitis as the predominant diseases referred by patients in the gynecological history recorded in the questionnaire in $C$. trachomatis infected women both seronegative and seropositive to HIV and also at physical exam. Those data are in agreement with previously published report. Paavonen et al. $(1987,1996)$ reported that $C$. trachomatis is one of the principal causes of PID and cervicitis.

Two women belonging to the control group referred infertility and both resulted infected with $C$. trachomatis, similar results have been found by other authors (Videla 
et al. 1994, Gao et al. 1995, Swasdio et al. 1996). In agreement with most of the literature reported, related to the symptomatic course of most $C$. trachomatis infection (Spinillo et al. 1994, Colvin et al. 1998) we demonstrated that a proportion of HIV seropositive women did not have any sign or symptoms at physical exam. Nevertheless it did not happen in the control group where all patients had positive physical exam.

We should take into account that many cases with negative results to $C$. trachomatis infection also presented a positive gynecological exam as well as symptoms recorded at the questionnaire; this could be explained due to the presence of other STI pathogens different of $C$. trachomatis such as Ureaplasma urealyticum, $T$. vaginalis, $N$. gonorrhoeae and $C$. albicans among others (Lan et al. 1995, German et al. 1997, Garland et al. 2001). Those agents were also tested in our study and we could detect that HPV and C. albicans were very frequent for HIV infected women and mycoplasma (U. urealiticum) for non-HIV group. Nevertheless there was no association between $C$. trachomatis and any other infection.

The $C$. trachomatis serovar was determined by RFLP analysis of the amplified nested PCR products, but only 7 cases could be typed, the other 3 were weakly positive and we were unable of typing them. Serovar $E$ was present in 6 cases, which is in agreement with previously published report (Frost et al. 1991, 1993, Lan et al. 1995) that considers this serovar as the most frequently detected in endocervical samples (about $40 \%$ of cases). Typing of $C$. trachomatis by mean of RLFP is a useful tool for epidemiological studies.

The present study is the first report of $C$. trachomatis prevalence in Cuba. It shows that not significant difference in the prevalence rate of $C$. trachomatis genital infection between both groups was found and serovar E was the most frequently detected. Patients referred history of PID, cervicitis and infertility. Cervicitis was the main clinical finding at gynecological exam and there were a proportion of asymptomatic patients. Strategies to detect and treat genital infections need to be developed.

\section{REFERENCES}

Adler MW 1996. Sexually transmitted diseases control in developing countries. Genitourin Med 72: 83-88.

Assefa A, Ishak A, Stevens R, Fergussen E, Giles M, Yohannes G, Kidan KG 1998. Prevalence of HIV, syphilis and genital chlamydial infection among women in Northwest Ethiopia. Epidemiol Infect 120: 171-177.

Calore E, Cavalier J, Kasumi S, Aranjo M 1995. Papillomavirus in cervical smears of women infected with human immunodefiency virus. Rev Paul Med 113: 1009-1011.

Chaisilwattana P, Chuachoowong R, Siriwasin W, Bhadrakom C, Mangclaviraj Y, Young N, Chearskul S, Chotpitayasunondh T, Mastro T, Shaffer N 1997. Chlamydial and gonococcal cervicitis in HIV-seropositive and HIV-seronegative pregnant women in Bangkok. Prevalence and risk factors, and relation to perinatal HIV transmission. Sex Transm Dis 24: 495-502.

Cheng H, Macaluso M, Vermund S, Hook E 2001. Relative accuracy of nuclei acid amplification tests and culture in detecting chlamydia in asymptomatic men. J Clin Microbiol 39: 3927-3937.
Christenson B, Stilstrom J 1995. The epidemiology of human immunodeficiency virus and other sexually transmitted diseases in the Stockholm area. Sex Transm Dis 22: 281-288.

Clark RA, Brandom W, Dumestre J, Pindaro C 1993. Clinical manifestation of infection with the human immunodeficiency virus in Louisiana. Clin Inf Dis 17: 165-172.

Colvin M, Abdool-Karim S, Connolly C, Hoosen A, Ntuki N 1998. HIV infection and asymptomatic sexually transmitted infections in a rural South African community. Int $J$ STD AIDS 9: 548-550.

Dawson S, Trapp R 1993. Bioestadística Médica, 3 ed., El Manual Moderno, México, p. 165-184.

Deák J, Nagy E, Véreb I, Mészáros G, Kovács L, Nyári T, Berbik I 1997. Prevalence of Chlamydia trachomatis infection in a low-risk population in Hungary. Sex Transm Dis 24: 538-542.

Douvier S, Sainte-Barbre C, Oudot C, Harbert F, Fritz M 1996. L'infection à Chlamydia trachomatis facteurs de risques. Contracept Fertil Sex 24: 391-398.

Fleming WH III, Hopkins JM, Lord GA 1977. New culture medium for presumptive identification of Candida albicans and Cryptococcus neoformans. J Clin Microbiol 5: 236243.

Fleis J 1981. Statistic Methods for Rates and Proportions, 2 ed., John Wiley \& Sons, New York, p. 135-156.

Fouts AC, Kraus SJ 1980. Trichomonas vaginalis: reevaluation of its clinical presentation and laboratory diagnosis. J Infec Dis 141: 137-143.

Frost E, Deslandes S, Bourgaux-Ramoisy D 1993. Chlamydia trachomatis serovars in 435 urogenital specimen typed by restriction endonuclease analysis of amplified DNA. J Infect Dis 168: 497-501.

Frost E, Deslandes S, Veilleux S, Bourgaux-Ramoisy D 1991. Typing Chlamydia trachomatis by detection of restriction fragment length polymorphism in the gene encoding the major outer membrane protein. J Infect Dis 163: 1103-1107.

Gao Z, Li Y, Chai D 1995. Investigation of cervical Chlamydia trachomatis infection in gynecological outpatients. Chung Hua Lue Hsing Ping Hsuch Tsa Chih 16: 211-212.

García Lechuz J, Rivera M, Catalán L, Sánchez-Carrillo C, Rodíguez-Céixems M, Bouza E 1999. Diferences in curable STDs between HIV and non-HIV population in Spain. Aids Patient Care STD 13: 175-177.

Garland S, Tabuzi S, Chen S, Byambaa C, Davaajav K 2001. Prevalence of sexually transmitted infections (Neisseria gonorrhoeae, Chlamydia trachomatis, Trichomonas vaginalis and human papillomavirus) in female attendees of a sexually transmitted diseases clinic in Ulaanbaatar, Mongolia. Infect Dis Obstet Gynecol 9: 143-146.

German M, Alary M, Guedeme A, Padonou F, Davo N, Adjovi C 1997. Evaluation of screening algorithm for the diagnosis of genital infections with Neisseria gonorrhoeae and Chlamydia trachomatis among female sex workers in Bénin. Sex Transm Dis 24: 109-115.

Hayes L, Bailey R, Mabey D, Clarke I, Pickett M, Watt P, Ward M 1992. Genotyping of Chlamydia trachomatis from a trachoma-endemic village in the Gambia by nested polymerase chain reaction: identification of strain variants. $J$ Infect Dis 166: 1173-1177.

Innis A, Golfand D, White T 1990. Sample preparation from blood, cells, and other fluids. In HB Jovanovich, PCR Protocols: a Guide Methods and Applications, Academic Press, San Diego, p. 356-367.

Lan J, Melgers I, Meijer M, Walboomers JM, Roosendal R, Burger C, Bleker O, van den Brule A 1995. Prevalence and serovar distribution of asymptomatic cervical Chlamydia 
trachomatis infection as determined by highly sensitive PCR. J Clin Microbiol 33: 3194-3197.

Le Bar WB 1996. Keeping up with new technology: New approaches to diagnosis of Chlamydia infection. Clin Chem 42: 809-812.

Manos MM, Ting Y, Wright DK, Lewis AJ, Broker TR, Woliusky SM 1989. The use of polymerase chain reaction amplification for detection of genital human papillomavirus. Cancer cells 7: 209-14.

Massé R, Laperriére H, Rousseau H, Lefebvre J, Remis R 1991. Chlamydia trachomatis cervical infection: prevalence and determinants among women presenting for routine gynecologic examination. Can Med Assoc 145: 953-961.

Minkoff H, Eisenberger-Matityahu D, Feldman J, Burk R, Clarke L 1999. Prevalence and incidence of gynecologic disorders among women infected with human immunodeficiency virus. Am J Obstet Gynecol 180: 824-836.

Naher H, Petzoldt D 1991. Chlamydia trachomatis serovars and the clinical picture of urogenital infections. Hautarzt 42: 298-301.

Oakeshott P, Hay P 1995. General practice update: Chlamydia infection in women. Br J Gen Pract 45: 615-620

Paavonen J, Teisala K, Heinonen p, Aine R, Laine S 1987. Microbiological and histopathological findings in acute pelvic inflammatory disease. Br J Obstet Gynecol 94: 454460.

Paavonen J 1996. Chlamydia trachomatis: a major cause of mucupurulent cervicitis and pelvic inflammatory disease in women. In P Elsner, A Eichmann (eds), Sexually Transmitted Diseases: Advances in Diagnostic and Treatment. Curr Probl Dermatol Basel Kanger 24: 110-122.
Passey M, Mgone C, Lupiwa S, Suve N, Tiwara S, Lupiwa T, Clegg A, Alpers M 1998. Communities based study of sexually transmitted diseases in rural women in the highlands of Papua New Guinea: prevalence and risk factors. Sex Transm Infect 74: 120-127.

Poulin C, Alary M, Bernier F, Carbonneau D, Boily M, Joly J 2001. Prevalence of Chlamydia trachomatis and Neiseria gonorrhoeae among at-risk women, young sex workers, and street youth attending community organizations in Quebec City, Canada. Sex Transm Dis 28: 437-443.

Ramjee G, Karim S, Sturm A 1998. Sexually transmitted infections among sex workers in KwaZulu-Natal, South Africa. Sex Trans Dis 25: 346-349.

Spinillo A, Gorini G, Regazzetti A, de Seta F, Nicola S, Zara C 1994. Asymptomatic genitourinary Chlamydia trachomatis infection in women. Obstet Gynecol 83: 1005-1010.

Swasdio K, Ragpao S, Tansachit T, Uttavichait C, Johgusak P, Uitayavanich T 1996. The association of Chlamydia trachomatis/gonococcal infection and tubal factor infertility. J Obstet Gynecol Res 22: 331-340.

Temmerman M 1994. Sexually transmitted diseases and reproductive health. Sex Transm Dis 21: S55-S58.

Teng K, Li M, Yu W, Li H, Shen D, Liu D 1994. Comparison of PCR with culture for detection of Ureaplasma urealyticum in clinical samples from patients with urogenital infections. J Clin Microbiol 32: 2232-2234

Thayer JD, Martin Jr JE 1966. An improved selective medium for cultivation of Neisseria gonorrhoeae and Neisseria meningitidis. Public Health Report 81: 559-562.

Videla C, Carballal G, Kekiklian G, Juarez C, Gómez M, Filippo E 1994. Chlamydia trachomatis and tubal obstruction sterility. Med B Aires 54: 6-12. 